\title{
The Practical Effect Observation of Flipped Classroom Mode Based on Professional Competence-Oriented in the Clinical Anesthesia Teaching
}

\author{
Lili Song $^{1, a}$ and Hongwei Zhang ${ }^{1, b^{*}}$ \\ 1Department of Anesthesiology, Third Affiliated Hospital of Qiqihar Medical University Taishun \\ Street, Tiefeng District, Qiqihar of Heilongjiang Province, China \\ ${ }^{2}$ Department of Anesthesiology, Third Affiliated Hospital of Qiqihar Medical University \\ a zs176@163.com, ${ }^{b}$ richardtom1@163.com \\ * The corresponding author
}

Keywords: Flipped classroom; Anaesthesiology; Three oriented; Teaching effect

\begin{abstract}
. through the practical effect observation results of flipped classroom model based on professional competence-oriented in the clinical anesthesia teaching, to exploring the best teaching model. Method: 89 students in two classes of the third grade of clinical medicine in our college were selected as the experimental group, flipped classroom model of professional competence-oriented was used in their clinical anesthesia teaching. 92 students in the other two classes from the same grade were selected as control groups, traditional teaching model was used in their clinical anesthesia teaching. All the students were examined by self-made simple teaching effect scale, and the theory and practice examination. Results: Teaching satisfaction and the satisfaction with self-help are both $98.88 \%$, the score of theoretical examination and practical ability examination was $44.5 \pm 7.1,43.2 \pm 5.0$ respectively. Compared with the control group, the increase was significant, and the difference was statistically significant $(\mathrm{P}<0.05)$. Conclusion: The flipped classroom model based on professional competence-oriented used in clinical anesthesia teaching, which can improve the teaching effect.

Anesthesiology is a clinical subject involving many basic medical courses, such as human anatomy, physiology, pharmacology, etc. The content of the teaching is abundant and abstract, if we continue to use the traditional method of teaching practice, it is bound to affect medical students on clinical anesthesiology intern enthusiasm, thus affecting the improvement of teaching quality [1]. Since 2011, our college has put forward the "three-oriented talent training model" in the Characteristic application-oriented undergraduate college construction program. The concept of "professional competence" oriented professional quality training has pointed out the specific research direction for the anesthetic teaching of clinical probationary students [2-3]. Then, according to the characteristics of anesthesiology, we propose the teaching model of clinical anesthesiology for medical students in our college. And the results are reported as follows.
\end{abstract}

\section{Research Object and Method}

Research Object. 89 students in two classes of the third grade of clinical medicine in Qiqihar medical college were selected as the experimental group, flipped classroom model of professional competence-oriented was used in their clinical anesthesia teaching. 92 students in the other two classes from the same grade were selected as control groups, traditional teaching model was used in their clinical anesthesia teaching. There were 41 boys and 48 girls in the experimental group, with an average age of $20.21 \pm 0.56$. And there were 43 boys and 49 girls in the control group, with an average age of $20.25 \pm 0.61$. There was no difference in sex and age between the two groups.

Research method. Experimental Group Teaching Model. This teaching model is constituted by three stages, preparation before class, in the class and after class. The preparatory work before class includes, (1)Collect and integrate a large amount of relevant literature, and then deep research on the teaching model of the flipping classroom, then comparing the traditional teaching model with the flipping classroom teaching model, and designing the clinical anesthetic teaching model of the flipping classroom. (2)According to the flipped classroom teaching model and the teaching 
objectives of each part, the teaching key and difficult points to design the teaching stage. Applied network resources and various software to make teaching videos, text materials and design the corresponding practice, and then upload to the network resource sharing platform, students learn QQ group and wechat group for student mobile phone terminal, computer terminal download, for they can learning, communication whenever and wherever possible [5]. (3)The students of the experimental group and the control group were investigated by questionnaire and anesthesia medicine-related knowledge test before the beginning of teaching. (4)A questionnaire was used to understand students' attitudes toward the anesthesiology course. Classroom teaching: according to the basic theory study, adopted the forms of objection raised during the panel discussion, discussion of objections among groups, the teacher appraises and scene imitation to the anesthetic practice content in classroom teaching. Post work: After the classroom teaching, the students in the experimental group were investigated with a questionnaire. The questionnaire is designed for the implementation of the model in teaching, which including pre-class teaching content communication, learning activities in class, evaluation of learning effect and general situation, and ensure that the effect of flipping classroom teaching model is analyzed from a quantitative perspective [6]. At the same time, the students in the experimental group were interviewed and exchanged by non-course teachers to understand the attitude and adaptability of the students to the flipping classroom teaching model, and their opinions. Through the exchange of teachers and students and the feedback of students' opinions and so on, the teaching scheme should be improved and revised in view of the problems and shortcomings in teaching.

Control Group Teaching Model. In the control group, the traditional ppt assisted classroom teaching model was used for 45 minutes of each class, in which the teacher taught for about 35 minutes, and the remaining time was used to organize the students to discuss or complete the classroom exercises and check the answers in class.

Observation Index. Self-made simple teaching effect evaluation scale has been used for many years in our school. It is mainly used to investigate the students' satisfaction with the teaching effect and their own help, the total score was 100, $\geq 90$ means very satisfaction, 76-90 means satisfaction, 60-75 means commonly, <60 means not satisfaction. Meanwhile, at the end of the term, the students are assessed through a self-made "theoretical and practical examination". The examination of theory and practice is mainly organized by the Clinical Anesthesiology Teaching and Research Department, 50 scores per item and total 100 points. The practice examination was carried out by three full-time teachers of clinical anesthesiology with rich experience and above senior titles.

Statistical Method. The data of questionnaire were input, arrangement and output by Epidata3.1, the data analyzed by spss $21.0, \mathrm{P}<0.05$ means there is a statistical difference.

\section{Results}

Comparison of Related Index of Teaching Effect. Teaching satisfaction and the satisfaction with self-help are both $98.88 \%$ in the experimental group, and compared with the control group, the increase was significant, and the difference was statistically significant $(\mathrm{P}<0.05)$. The results were shown in Table 1.

Table 1 Comparison of related index of teaching effect between the two groups

\begin{tabular}{|c|c|c|c|c|c|c|c|c|c|c|c|}
\hline \multirow[t]{2}{*}{ Group } & \multirow[t]{2}{*}{ Cases } & \multicolumn{5}{|c|}{ Teaching satisfaction } & \multicolumn{5}{|c|}{ Satisfaction with self-help } \\
\hline & & $\begin{array}{l}\text { Very } \\
\text { satisfa } \\
\text { ction }\end{array}$ & $\begin{array}{l}\text { Satisf } \\
\text { actio } \\
n\end{array}$ & $\begin{array}{l}\text { Com } \\
\text { monl } \\
\mathrm{y}\end{array}$ & $\begin{array}{l}\text { Not } \\
\text { satisfa } \\
\text { ction }\end{array}$ & $\begin{array}{l}\text { Degree of } \\
\text { satisfaction } \\
(\%)\end{array}$ & $\begin{array}{l}\text { Very } \\
\text { satisfa } \\
\text { ction }\end{array}$ & $\begin{array}{l}\text { Satis } \\
\text { facti } \\
\text { on }\end{array}$ & $\begin{array}{l}\text { Com } \\
\text { monl } \\
\mathrm{y}\end{array}$ & $\begin{array}{l}\text { Not } \\
\text { satisfa } \\
\text { ction }\end{array}$ & $\begin{array}{l}\text { Degree of } \\
\text { satisfaction } \\
(\%)\end{array}$ \\
\hline $\begin{array}{l}\text { Experi } \\
\text { mental } \\
\text { group }\end{array}$ & 89 & 48 & 33 & 7 & 1 & 98.88 & 42 & 39 & 7 & 1 & 98.88 \\
\hline $\begin{array}{l}\text { Contro } \\
1 \text { group }\end{array}$ & 92 & 20 & 36 & 19 & 17 & $81.52^{\wedge}$ & 16 & 30 & 24 & 22 & $76.08^{\wedge}$ \\
\hline
\end{tabular}

Note: Comparison with control group, $\mathbf{\Delta} \mathrm{P}<0.05$ 
Comparison of Theoretical and Practical Abilities. Compared with the control group, the theoretical and practical abilities of the experimental group increased significantly, and the difference was statistically significant $(\mathrm{P}<0.05)$. The results are shown inTable 2 .

Table 2 Comparison of theoretical and practical abilities between the two groups (scores)

\begin{tabular}{llll}
\hline Group & Cases & $\begin{array}{l}\text { Theoretical } \\
\text { examination }\end{array}$ & $\begin{array}{l}\text { Practical } \\
\text { examination }\end{array}$ \\
\hline $\begin{array}{l}\text { Experiment } \\
\text { al group }\end{array}$ & 89 & $44.5 \pm 7.1$ & $43.2 \pm 5.0$ \\
$\begin{array}{l}\text { Control } \\
\text { group }\end{array}$ & 92 & $26.7 \pm 7.7^{\mathbf{\Delta}}$ & $25.1 \pm 5.2^{\mathbf{\Delta}}$ \\
\hline
\end{tabular}

Note: Comparison with control group, $\mathbf{\Delta} \mathrm{P}<0.05$

\section{Discussion}

Flipped classroom model is a new teaching model based on information means that has become more and more popular in recent years. The aim is to make full use of classroom time, realize individualized learning, and promote the development of autonomous learning ability and cooperative learning consciousness [7]. According to the "professional competence" oriented professional quality training requirements of "Three-oriented Talent training Model", the teaching model of flipping classroom accords well with the direction of the teaching reform of the "Three-oriented talent training model" at present, and it has also become one of the teaching models which attracted clinical teachers [8]. Based on the current situation of clinical anesthesiology teaching, this research lead Flipping classroom teaching model into clinical anesthesia teaching of the medical college, and to explore effective ways to improve teaching quality of clinical anesthesia. And in the course of the research, the effect of the teaching practice under the teaching model is tested, and the practical experience is provided for the implementation of the flipping classroom in clinical teaching in medical colleges and universities. It is of great significance to improve the teaching of clinical medicine and improve the autonomous learning ability of medical students.

In view of this, in the clinical teaching process, the teaching and research department has introduced the "professional competence" oriented flipping classroom model. The results showed that, teaching satisfaction and the satisfaction with self-help are both $98.88 \%$ in the experimental group, and compared with the control group, the increase was significant, and the difference was statistically significant $(\mathrm{P}<0.05)$. The reason may be that the application of flipping classroom can better relate the theory to practice. And compared with the previous teaching model which emphasizes the theory and neglects the student's experience, it can stimulate the students' interest in learning. Furthermore, in the previous teaching, the students were passive to accepted the knowledge, but in this model it belongs to active participation, even they are the organizer and they can construct knowledge actively. Research has confirmed that people can learn $10 \%$ by reading, and $80 \%$ by experience [9]. Additionally, in the previous teaching, the communication between teachers and students was unidirectional, while experiential teaching is two-way, even multi-directional. Through the exchange and communication between teachers and students, we can get rich experience, and realize the unification of knowledge and skill, process and method, emotional attitude and value [10].

\section{Acknowledgement}

This paper is supported by Educational Research Project of Qiqihar Medical University (Project Number QYJY20170250), and the 13th Five-Year Planning Youth Innovation Project of China Association for Educational Technology (Project Number G010) 


\section{Reference}

[1] Ministry of education, National Health and Family Planning Commission, State Administration of Traditional Chinese Medicine, etc. Opinions on the deepening reform of clinical medical talents training with the cooperation of medical education[EB/OL].(2014-11-27)[2015-06-30].

[2] Tong J, Zhang L, Du WX, etc. Analysis on the present situation and demand of Public elective courses of Medicine and Non-medical majors in Medical Colleges and Universities[J]. Journal of Modern Medicine \& Health, 2015, (13):2059-2062.

[3] Liu C, Pu LJ, Xiao JY. Reflections on improving the Teaching quality of Public elective courses in Medical Colleges and Universities under the background of Teaching Reform[J]. China Continuing Medical Education, 2016, (35):2-4.

[4] Miao JM, Wang Q. Flipping classroom mode in colleges and universities: Status, effectiveness and challenges-A survey based on front-line teachers[J]. Open Education Research, 2015, (05):74-82.

[5] Zhang TY. The Reflection and Examine on the Teaching of "Flipping classroom mode" in Colleges and Universities[J]. Education Teaching Forum, 2017, (02):208-210.

[6] Liu P. A Summary of the Research on flipping classroom[J]. Education Modernization, 2016, 18 (2):168-170.

[7] Zhang JL, Wang Y. Research on Zhang Baohui's flipping classroom Teaching Model[J]. Journal of Distance Education, 2012, 21 (4):46-51.

[8] Zhong XL, Song SQ, Jiao LZ. Research on Teaching Design based on the idea of flipping classroom in the Information Environment[J]. Open Education Research, 2013, 19 (1):58-64

[9] Ma JJ, Liu SJ, Chen BL. Discussion on teacher's role in Clinical practice Teaching under the Mode of flipping classroom[J].Basic Medical Education, 2015, 17(6):528-532.

[10] Meng LJ, Song YX, Liu TB, etc. A probe into the Comprehensive quality Evaluation of Medical students under the "three orientation" Talent training Mode-Take Qiqihar Medical College as a sample[J].Medical Education Management, 2017, (4):254-28. 